\title{
Comparison of Biological Attributes of Culex quinquefasciatus (Diptera: Culicidae) Populations from India
}

\author{
Mangesh D. Gokhale, Mandar S. Paingankar, and Sachin D. Dhaigude \\ Department of Medical Entomology and Zoology, National Institute of Virology, Microbial Containment Complex, \\ 130/1 Sus Road, Pashan, Pune 411021, India \\ Correspondence should be addressed to Mangesh D. Gokhale; gokhale40@gmail.com
}

Received 27 April 2013; Accepted 2 June 2013

Academic Editors: A. I. Kehr and M. V. Micieli

Copyright (C) 2013 Mangesh D. Gokhale et al. This is an open access article distributed under the Creative Commons Attribution License, which permits unrestricted use, distribution, and reproduction in any medium, provided the original work is properly cited.

\begin{abstract}
Understanding the population dynamics of mosquito populations through life table analysis and insecticide susceptibility is important to assess the likely impact of vector control strategies as well as to aid the design of novel interventions. Variation in the life tables and other biological data was compared for two populations of Culex quinquefasciatus Say 1823 from geographically isolated regions, Gorakhpur and Pune from India. Under a standardized rearing regime and constant laboratory conditions, mosquitoes were reared and biological attributes of these populations were compared. Development and survival of immature and adult stages of Culex quinquefasciatus were found significantly different in Gorakhpur and Pune populations. Principal component analysis of morphological data revealed that the two populations form significantly different clusters which can be differentiated from each other based on siphon, saddle, anal gills, and pecten teeth related variables. Insecticide susceptibility results suggest that the larvae from both areas were more susceptible to deltamethrin as compared to DDT and malathion. The current study provides baseline information on survivorship, morphological variation and insecticide susceptibility of Culex quinquefasciatus. The results obtained in this study suggest that different geographical areas with contrasting habitats have significant influence on survival and reproductive strategies of Culex quinquefasciatus.
\end{abstract}

\section{Introduction}

Feasible mosquito intervention strategies require in-depth knowledge of the population dynamics and insecticide susceptibility status. To better understand the population dynamics of the vector species, understanding the parameters such as development time, rate of survival, and fecundity of particular importance. A life table describes the development, survival, and fecundity of a cohort and provides basic data on population growth parameters. Life table study also provide, concise information on inherent differences in the survivorship and reproductive strategies of populations under different ecological regimes [1] and can help in explaining why certain species proliferate in particular environments.

Culex quinquefasciatus Say is a cosmopolitan mosquito species found in tropical, subtropical, and warm temperate regions. Cx. quinquefasciatus acts as a vector of filarial worms $[2,3]$, protozoan parasites [4], and various arboviruses [59]. In India, $C x$. quinquefasciatus is the principal vector of bancroftial filariasis [10]. Rapid urbanization and industrialization without proper drainage facilities are responsible for the establishment of the $C x$. quinquefasciatus in various cities of India [11]. Of the estimated global 128 million lymphatic filarial cases, 91 per cent are caused by Wuchereria bancrofti Cobbold [12]. India alone contributes 40 per cent to the world's lymphatic filariasis disease burden [13]. The estimates of disease burden due to filariasis suggest that 2.06 million disability adjusted life years (DALYs) are lost in India [14].

Numerous studies have been carried out on $C x$. quinquefasciatus biology and insecticide susceptibility [15-28]. Recently, Suman et al. $[25,28]$ reported significant variations in morphology among eggs and life table attributes from the four strains of $C x$. quinquefasciatus. Comparison of biological attributes such as insecticide susceptibility, life table analysis, and morphological variation of $C x$. quinquefasciatus of endemic and nonendemic areas of lymphatic filariasis is not well documented. 
Mosquitoes inhabiting in distinct location normally adapt to local conditions. Gorakhpur and Pune are geographically well separated $(\sim 1500 \mathrm{~km})$ (Figure 1$)$ and having different climatic conditions. Uttar Pradesh (Gorakhpur) is one of the lymphatic filariasis endemic states of the India whereas Maharashtra (Pune) is nonendemic to lymphatic filariasis. The environment and climatic features of these two ecotypes are also different. It seems possible that environmental stress of these two ecoclimatic regions influence their life history traits. We hypothesized that these mosquito strains will differ in their life table and biological attributes because they appear to be adapted to their respective local environments. To test this hypothesis, we investigated the life table analysis, morphological variation, and insecticide susceptibility between these two populations of $C x$. quinquefasciatus from geographically well-separated areas in India, namely, Gorakhpur and Pune.

\section{Materials and Methods}

2.1. Ethics Statement. All animals were handled in strict accordance with good animal practice as defined by Institutional Animal Ethics Committee (IAEC) affiliated with National Institute of Virology (NIV), Pune, India. All animal work was approved by the IAEC. Animal experiments were carried out in strict compliance with Committee for the Purpose of Control and Supervision of Experiment on Animals (CPCSEA) guidelines, India.

2.2. Mosquito Collection and Rearing. Adult and larvae of $C x$. quinquefasciatus were sampled from two populations to examine the possibility of population differences in the endemic and nonendemic areas of lymphatic filariasis infection. Uttar Pradesh is an endemic area of JE virus and lymphatic filariasis infection and Maharashtra is nonendemic to JE virus and lymphatic filariasis infections. Gorakhpur $\left(26^{\circ} 45^{\prime} \mathrm{N}, 83^{\circ} 24^{\prime} \mathrm{E}\right)$ is situated in the Tarai belt near Himalaya ranges in Uttar Pradesh state bordering Nepal whereas Pune $\left(18^{\circ} 31^{\prime} \mathrm{N}, 73^{\circ} 55^{\prime} \mathrm{E}\right)$ is situated near Western Ghats of India, in Maharashtra state. Gorakhpur is situated in the Indo-Gangetic Plain region that receives $1200-1300 \mathrm{~mm}$ of rainfall per year. Annual temperature ranges between $8^{\circ} \mathrm{C}$ in winter and $42^{\circ} \mathrm{C}$ in summer. The vegetation of this region is tropical, moist, and deciduous. Pune is situated in a semiarid region that receives $700-800 \mathrm{~mm}$ of rainfall per year. Annual temperature ranges between $12^{\circ} \mathrm{C}$ in winter and $38^{\circ} \mathrm{C}$ in winter. The vegetation of this region is dry deciduous. Larvae were collected from temporary and semipermanent ground water pools and fields. Morphometric analysis was carried out on these field collected mosquitoes. In the present study, to better understand baseline parameters of the life cycle of Culex quinquefasciatus, colonies of this species from two different ecological areas were monitored under laboratory conditions for life table analysis and insecticide susceptibility. Individuals of $C x$. quinquefasciatus were identified using keys of Barraud [29]. Voucher specimens were deposited in National Institute of Virology museum, Pune, India.
2.3. Life Table Analysis. Rearing of mosquito in laboratory environment imposes a certain degree of selection pressure on mosquito biology. Mosquito colonies were maintained in standardized environmental conditions which were favorable to mosquito survival. Hence, we assume that life-table parameters derived from data collected from the colonized wild strains represent maximum estimates of their life-table parameters and are likely to reflect true differences between geographically isolated strains. Similar assumptions were made earlier by Reisen et al. [30] and Suman et al. [28] to compare the life-table attributes of geographically distinct strains of Culex mosquitoes.

Colonies of each population were maintained at National Institute of Virology Pune in standard laboratory conditions at $28 \pm 1^{\circ} \mathrm{C}, 70 \pm 5 \%$ relative humidity $(\mathrm{RH})$ and light: dark (LD) $12: 12 \mathrm{~h}$. These colonies were maintained for up to seven generations (approximately 4 months). The adults were offered $10 \%$ glucose solution soaked in cotton pads daily, as a source of nutrition. A fowl was provided as a source of blood twice a week. Fowls were maintained in accordance with approved guidelines of the Committee for the Purpose of Control and Supervision of Experiments on Animals (CPCSEA) India. Egg rafts were collected from the individual mosquitoes in plastic cups $(60 \mathrm{ml})$ containing water and lined with filter papers, in the cage. The single egg raft was transferred from the filter papers with the aid of mounting needles into plastic bowls $(10 \mathrm{~cm}$ height and $25 \mathrm{~cm}$ diameter) where they were held for 24 to $72 \mathrm{~h}$ for hatching. Twenty-four hours after hatching, the larvae were maintained at a density of 100 larvae per tray $(45 \times 30 \times$ $10 \mathrm{~cm}$ ) containing $2 \mathrm{~L}$ of dechlorinated water. The larvae were fed with mixture of yeast extract and dog biscuit powder, sprinkled on the water surface. On every alternate day, the water from the culture tray was changed carefully until pupation. The pupae were separated from the larvae daily and placed in plastic bowls $(10 \mathrm{~cm}$ height and $30 \mathrm{~cm}$ diameter) half-filled with water. These plastic bowls with pupae were placed in adult-holding cages for emergence. Adults after emergence were offered $10 \%$ glucose solution soaked in cotton pads daily. Fecundity was estimated based on the average numbers of eggs laid per female. Egg-hatching rate was estimated from the number of eggs hatched per female. Duration of the preadult development periods was determined by observing each pan daily, and all larval skins were removed, scored to instar, and counted. There were two replicates for each experiment described above and the whole study was repeated three times, resulting in the monitoring of about 600 larvae from first instar stage to adulthood.

2.4. Survival Analysis. One hundred newly emerged larvae were placed in basins. All basins were screened with white, insect-proof, nylon netting to prevent colonization by other mosquitoes and predators. Each day the number of larvae alive and their stage of development were counted and recorded. Adult mosquitoes that emerged were counted daily, and the sexes were recorded. Standard life table analysis 

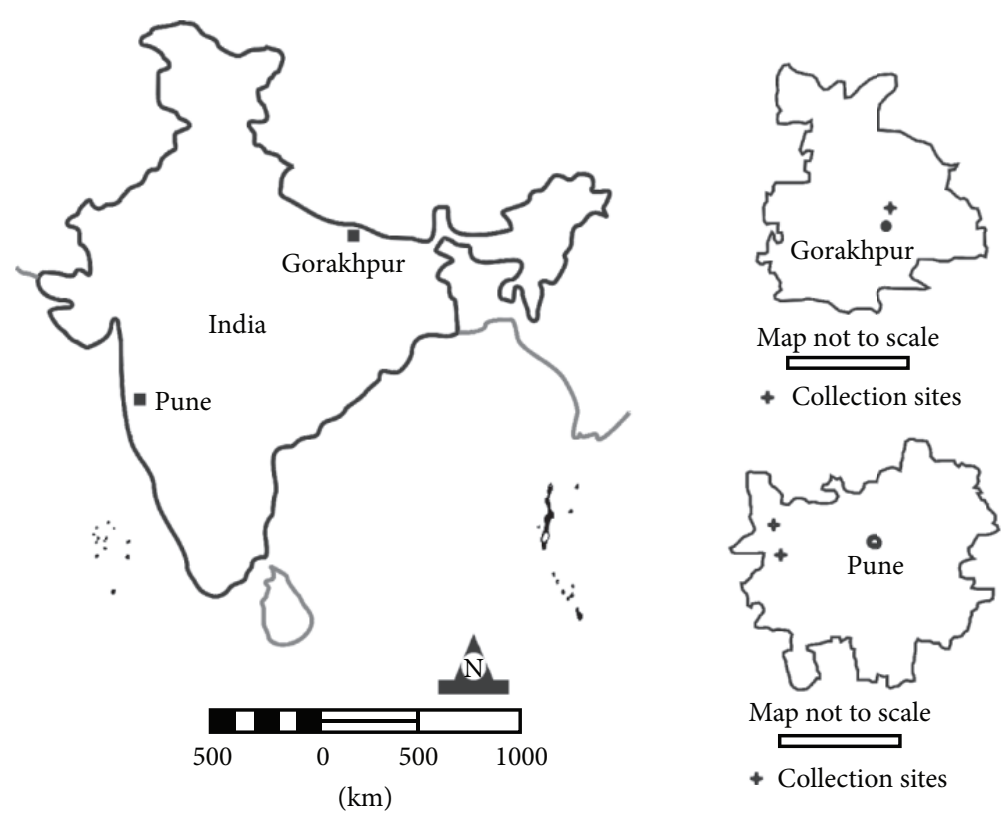

FIGURE 1: The sampling map $\mathbf{m}$ indicates the sampling locations.

was performed on the data (Table 1). Computation of stagespecific survivorship was according to the formula:

$$
S_{i}=\frac{n_{i}}{\left(x n_{i}-1\right)} \times 100 ;
$$

where $n_{i}$ is the number of individuals entering stage $i$ and $\left(x n_{i}-1\right)$ is the number of individuals that entered the preceding stage.

2.5. Morphological Analysis. Field collected larvae were used for morphometric analysis. Eight morphological characters and three ratios were scored for morphological analysis of fourth instar larvae (Table 3). Siphon index, anal gill index, and siphon saddle ratio are used in traditional taxonomy to distinguish among species and subspecies. However, Fakoorziba and Vijayan [31] and Kanojia et al. [32] have used these ratios even to distinguish between different populations. The characters of fourth-instar larvae were measured using micrometric oculars with the least count $0.01 \mathrm{~mm}$.

2.6. Adult Mosquito Bioassays. Insecticide susceptibility tests were carried out using the standard WHO protocol, insecticide susceptibility test kits, and impregnated papers. Twoto three-day-old nonblood-fed adult female $C x$. quinquefasciatus were tested. Three batches of 20 mosquitoes each were exposed to test papers impregnated with DDT (4\%), Deltamethrin (0.05\%), and Malathion (5\%). Controls included batches of mosquitoes from each site exposed to untreated papers.

2.7. Larval Bioassays. Batches of fourth instars were exposed to insecticide solution (DDT, Deltamethrin and Malathion) diluted in distilled water. Twenty larvae per concentration and five concentrations per test, providing mortalities ranging from 0 to $100 \%$, were run. Temperature was maintained at
TABLE 1: Mean duration and survival rates of life stages of $C x$. quinquefasciatus.

\begin{tabular}{|c|c|c|}
\hline Attribute & $\begin{array}{c}\text { Culex } \\
\text { quinquefasciatus } \\
\text { Gorakhpur } \\
\text { Mean (SD) }\end{array}$ & $\begin{array}{c}\text { Culex } \\
\text { quinquefasciatus } \\
\text { Pune } \\
\text { Mean (SD) }\end{array}$ \\
\hline \multicolumn{3}{|l|}{ Survival rates } \\
\hline (1) \% Egg hatching & $86.5( \pm 7.3)$ & $91.5( \pm 3.8)$ \\
\hline (2) \% Larval survival & $42( \pm 3)$ & $68( \pm 7)$ \\
\hline (3) \% Pupal survival & $85.99( \pm 3.76)$ & $90.06( \pm 3.38)$ \\
\hline (4) \% Total survival & $28( \pm 0.76)$ & $58.06( \pm 3.61)$ \\
\hline \multicolumn{3}{|l|}{ Developmental parameters } \\
\hline (5) Egg hatching period & $1.8( \pm 0.5)$ days & $1.6( \pm 0.6)$ days \\
\hline (6) Larval duration & $13.33( \pm 2.1)$ days & $\begin{array}{c}14.57( \pm 1.86) \\
\text { days }\end{array}$ \\
\hline (7) Pupal duration & $2.1( \pm 0.3)$ days & $1.9( \pm 0.5)$ days \\
\hline (8) \% Males emerged & $48.53( \pm 2.82)$ & $50.39( \pm 6.53)$ \\
\hline (9) \% Females emerged & $51.46( \pm 2.81)$ & $49.60( \pm 6.53)$ \\
\hline (10) Male : female ratio & 0.94 & 1.01 \\
\hline
\end{tabular}

$28^{\circ} \mathrm{C}$ throughout the test, and larval mortality was recorded after $1 \mathrm{~h}$ exposure and then corrected for control mortality [33]. Three replicates with insect larvae from different rearing batches were made at different times, and the results were pooled. The data were subject to a log-probit analysis [34] to determine the $\mathrm{LC}_{50}$ and $\mathrm{LC}_{95}$ values as well as their $95 \%$ confidence intervals (CI).

2.8. Analysis of Data. Survival was evaluated by scoring the number of dead mosquitoes/larvae every day, to estimate mosquito stage specific lifespan. Larvae those who are 
entered in pupal stage were considered as censored data. The survival rate for each mosquito population was described using life table analysis. These survival curves were then compared using the logrank test. Pairwise comparison of each character was carried out using $t$-test, with the Bonferroni adjustment to the probabilities (as 11 comparisons were made therefore we used $\alpha=0.0045$ as our cutoff value). Data were analyzed using multivariate statistics. Multivariate analysis offers the advantage of taking into account all the variables in a single analysis, thus making it possible to assess variation in the morphological characters of larvae from different collection sites. Principal component analysis (PCA) was done to create uncorrelated principal components from the original variables. Factor scores estimate the actual values of individual observations for the factors, whereas correlation between variables and factors is called as factor loading. Principal components were extracted from the covariance matrix. Mean values (centroids) and 95\% asymptotic confidence limits of the scores of individual larvae on the first two principal components were computed for each sample. First two principal factors, which explained maximum variation in the data, were analyzed to understand the variation in the morphology of different individuals.

2.9. Analysis of Bioassay Data. Bioassay data were pooled and analyzed ( $\mathrm{LC}_{50}$ and 95\% LC values) by using SPSS ver. 16 program (SPSS Inc., Chicago, IL).

2.9.1. Abbott's Formula. Bioassay data were not considered if the control mortalities were $>20 \%$. Actual mortalities were calculated against control mortalities by using Abbott's formula [33]. Corrected mortality $=(\%$ survival in control experiment - \% survival in treated experiment $) /(\%$ survival in control experiment) $\times 100$.

2.9.2. Log-Probit Regression Lines. Log-probit regression lines were obtained by plotting percentage mortalities ( $Y$ axis-probability) against concentration ( $X$ axis-log). $\mathrm{LC}_{50}$ (dosage which kills $50 \%$ of the population) and $\mathrm{LC}_{95}$ (dosage which kills $95 \%$ of the population) values were obtained. Fitness of the regression lines was statistically tested using $\chi^{2}$ values [35].

\section{Results}

3.1. Preadult Development and Survival. The mean duration and survival rates of different life stages of $C x$. quinquefasciatus of Gorakhpur and Pune are depicted in Table 1. The percentage of egg hatching was lower in Gorakhpur (86.5 \pm 7.3$)$ as compared to Pune $(91.5 \pm 3.8)$. Larval-to-adult survival rate of $C x$. quinquefasciatus in Pune (58.063.61) was significantly higher than Gorakhpur $(28 \% \pm 0.76)(t$-test $P<0.001)$. Pune population of $C x$. quinquefasciatus had slightly longer larval development time (14.57 days) when compared with that of Gorakhpur Cx. quinquefasciatus population (13.33 days). Larval survival rate of Pune population (68\%) was higher than Gorakhpur population (42\%) of Cx. quinquefasciatus ( $t$ test $P<0.01)$. Pupal survival rates of both populations were
TABLE 2: Comparison of biological attributes in Cx. quinquefasciatus.

\begin{tabular}{lcc}
\hline Attribute & $\begin{array}{c}\text { Culex } \\
\text { quinquefasciatus } \\
\text { Gorakhpur } \\
\text { Mean (SD) }\end{array}$ & $\begin{array}{c}\text { Culex } \\
\text { quinquefasciatus } \\
\text { Pune } \\
\text { Mean (SD) }\end{array}$ \\
\hline (1) Largest egg raft & 186 & 160 \\
(2) Smallest egg raft & 151 & 121 \\
(3) Number of eggs per raft & $169(14.5)$ & $139.75(15.96)$ \\
(4) Eggs/female/day & $32.19(1.68)$ & $26.59(2.45)$ \\
(5) Eggs/female life span & $676(32)$ & $559(36)$ \\
\hline
\end{tabular}

TABLE 3: Comparison of morphological characters of two populations of Culex quinquefasciatus.

\begin{tabular}{|c|c|c|c|c|}
\hline \multirow[t]{2}{*}{ Character } & \multicolumn{2}{|c|}{$\begin{array}{c}\text { Culex quinquefasciatus } \\
\text { Gorakhpur }(n=24)\end{array}$} & \multicolumn{2}{|c|}{$\begin{array}{c}\text { Culex quinquefasciatus } \\
\text { Pune }(n=25)\end{array}$} \\
\hline & Mean (SD) & Min-Max & Mean (SD) & Min-Max \\
\hline Comb scale & $33.72(6.67)$ & $25-46$ & 37.89 (7.12) & $26-50$ \\
\hline $\begin{array}{l}\text { Denticles on } \\
\text { apical pecten } \\
\text { tooth }^{* \dagger}\end{array}$ & $9.53(0.75)$ & $8-10$ & $10(1.54)$ & $7-12$ \\
\hline Pecten teeth & $4.90(0.54)$ & $4-6$ & $4.78(0.43)$ & $4-5$ \\
\hline $\begin{array}{l}\text { Length of } \\
\text { siphon* }\end{array}$ & $1.01(0.12)$ & $0.74-1.12$ & $1.07(0.06)$ & $1.01-1.19$ \\
\hline $\begin{array}{l}\text { Width of } \\
\text { siphon }\end{array}$ & $0.30(0.03)$ & $0.27-0.38$ & $0.31(0.02)$ & $0.27-0.34$ \\
\hline Siphon index & $3.30(0.47)$ & $2.56-4$ & $3.54(0.46)$ & $2.94-4.4$ \\
\hline $\begin{array}{l}\text { Length of } \\
\text { saddle }^{* \dagger}\end{array}$ & $0.35(0.03)$ & $0.29-0.39$ & $0.33(0.02)$ & $0.29-0.36$ \\
\hline $\begin{array}{l}\text { Siphon/saddle } \\
\text { ratio }^{* \dagger}\end{array}$ & $2.84(0.36)$ & $2.04-3.22$ & $3.24(0.25)$ & $2.9-3.62$ \\
\hline $\begin{array}{l}\text { Length of anal } \\
\text { gills }^{*}\end{array}$ & $0.83(0.07)$ & $0.72-0.9$ & $0.69(0.18)$ & $0.36-0.93$ \\
\hline $\begin{array}{l}\text { Width of anal } \\
\text { gills }\end{array}$ & $0.11(0.02)$ & $0.09-0.14$ & $0.12(0.03)$ & $0.09-0.18$ \\
\hline $\begin{array}{l}\text { Anal gill } \\
\text { index }^{* \dagger}\end{array}$ & 7.78 (1.31) & $5.75-10$ & $5.97(1.25)$ & $4-8$ \\
\hline
\end{tabular}

*Significantly different $(t$-test $P<0.05)$.

${ }^{\dagger}$ Significantly different after Bonferroni correction ( $t$-test $\alpha=0.0045$ cutoff value after Bonferroni correction).

not significantly different ( $t$-test $P>0.05)$. No significant difference was observed in male female emergence ratio $(t$ test $P>0.05)$. Survival rate of $C x$. quinquefasciatus adults of Pune was higher than those of Gorakhpur (logrank test; $\chi^{2}=12.1$ on 1 degrees of freedom, $P=0.000493$ ) (Figure 2).

3.2. Fecundity. Comparison of egg production of Gorakhpur population and Pune population of $C x$. quinquefasciatus is reported in Table 2. Gorakhpur population produced bigger egg raft (151-186 eggs) as compared to Pune population (121160 eggs). The number of eggs per raft were higher in Gorakhpur population $(169 \pm 14.5)$ as compared to Pune population $(139.75 \pm 15.96)$ (Table 2). The number of eggs/female life span was higher in Gorakhpur population (676 \pm 32) (Table 2). 


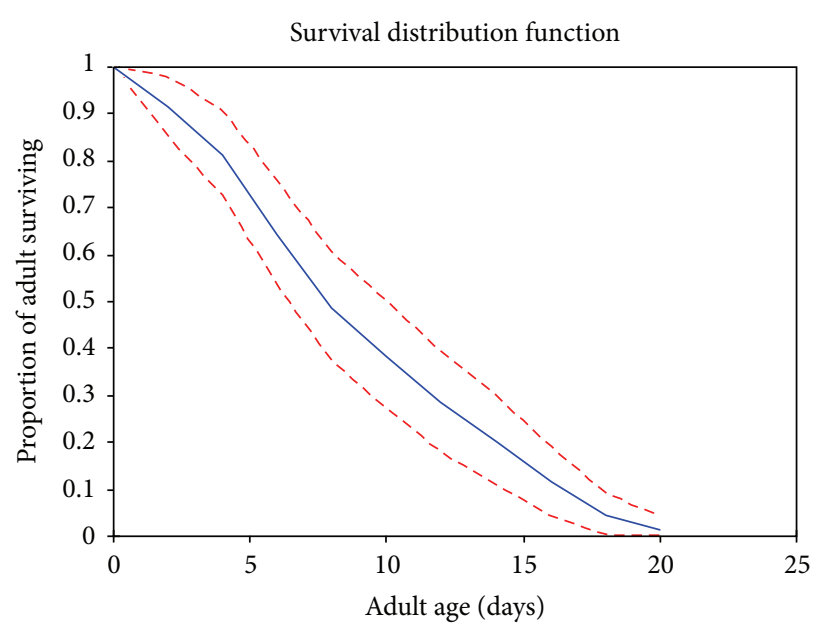

(a)

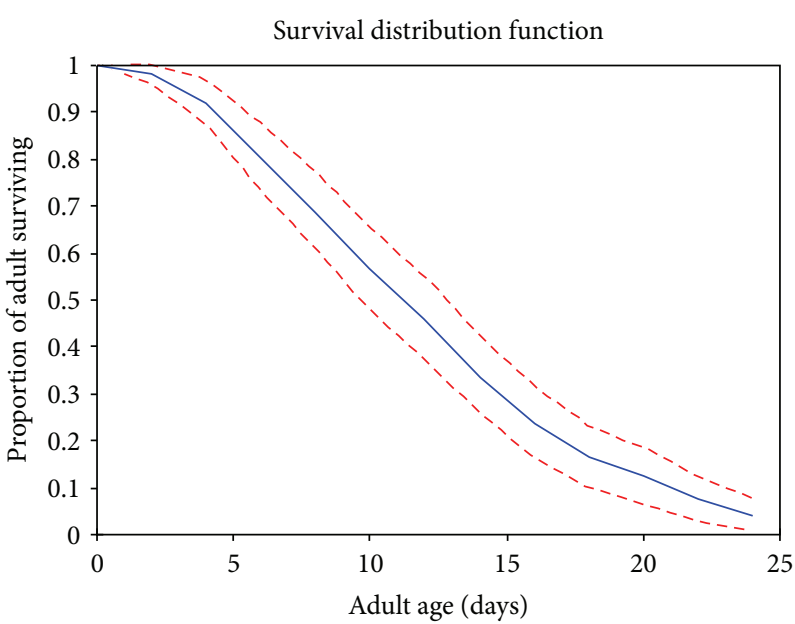

(b)

Figure 2: Survivorship curves of Cx. quinquefasciatus of Gorakhpur and Pune. (a) Adult survivorship curve of Gorakhpur population. (b) Adult survivorship curve of Pune population. The survival rate for each mosquito population was described using life table analysis and was compared using the logrank test.

Eggs/female/day was ranged from 32.19 (1.68) in Gorakhpur population and 26.59 (2.45) in Pune population (Table 2).

3.3. Phenotypic Variation among the Populations. The pairwise comparison of morphological characters using unpaired $t$-test revealed that characters like length of anal gills, length of siphon, denticles on the apical pecten teeth, siphon saddle ratio, and anal gill index were significantly different in both populations studied (Table 3). PCA of the morphological analysis extracted four factors with eigenvalues more than one. Cumulatively, these factors explained $79.61 \%$ of the total variability in the data. The first factor (F1) explained 31.97\% of the total variability while the second factor (F2) explained $19.73 \%$ of total variability and together the first two factors explained $51.70 \%$ of the total variability. Characters which showed high factor loading on F1 included length of siphon, width of anal gill, siphon index, and siphon/saddle ratio, while characters which showed high factor loading on F2 included length of anal gill, length of saddle, and anal gill index. PCA could distinguish two significant clusters for $C x$. quinquefasciatus of Pune, Cx. quinquefasciatus of Gorakhpur (Figure 3). Our null hypothesis that there is no significant difference in morphometry of $C x$. quinquefasciatus populations was rejected.

3.4. Insecticide Susceptibility. Based on WHO criteria [36], Cx. quinquefasciatus from Gorakhpur and Pune showed complete susceptibility to deltamethrin ( $100 \%$ mortality), potential resistance to malathion ( $\sim 80 \%$ mortality), and complete resistance to DDT (Less than $80 \%$ mortality). No significant difference was noted in the toxicity of diagnostic concentrations of DDT, deltamethrin, and malathion between the Gorakhpur and Pune populations of $C x$. quinquefasciatus ( $t$ test $P>0.05$ ). The larvicidal potency of DDT, deltramethrin, and malathion against $C x$. quinquefasciatus is depicted in Table 4. Gorakhpur population showed higher $\mathrm{LC}_{50}$ value for DDT and malathion as compared to Pune population.
No significant difference was observed for $\mathrm{LC}_{50}$ values of deltamethrin for both the populations.

\section{Discussion}

The effects of geographical and environmental events on life table attributes and morphological structure of local populations of $C x$. quinquefasciatus were analyzed in this study. Our null hypothesis that there is no significant difference between the life cycle parameters, morphology, and profiles of Gorakhpur and Pune populations was rejected. Gorakhpur and Pune populations of $C x$. quinquefasciatus are significantly different with respect to life table attributes and morphological characters.

Gorakhpur and Pune are $~ 1500 \mathrm{~km}$ apart, Gorakhpur area having the higher range of annual temperatures, lower relative humidity for most of the year, and higher annual rain fall as compared to Pune. Accordingly, we might expect that environmental conditions in Pune would favour survival and reproductive potential of mosquitoes. The population from Gorakhpur area exposed to harsh conditions for survival in nature than Pune strain had a shorter life expectancy (20-23 days in Gorakhpur vs $24-27$ days in Pune), laid eggs on most days (18-20 days in Gorakhpur vs 20-22 days in Pune), and constructed larger egg rafts (169 \pm 14.5 eggs/raft in Gorakhpur vs $139.75 \pm 15.96$ eggs/raft in Pune), indicating that Gorakhpur strain invested the most energy in rapid reproduction. The higher survivorship of adult $C x$. quinquefasciatus in the Pune compared to the Gorakhpur is likely caused because of favorable habitat and environmental conditions in Pune.

The percentage of eggs hatching was not significantly different in Gorakhpur $(86.5 \pm 7.3)$ population as compared to Pune $(91.5 \pm 3.8)(t$-test $P>0.05)$. The percentage of eggs hatching has been reported to be $82.1 \%$ in Culex pipiens 
TABLE 4: Comparative toxicity of DDT, deltamethrin, and malathion against populations of Cx. quinquefasciatus tested at the larval stage (larval bioassays).

\begin{tabular}{|c|c|c|c|c|c|c|c|c|}
\hline \multirow{2}{*}{ Insecticide } & \multirow{2}{*}{$\begin{array}{l}\text { Cx. quinquefasciatus } \\
\text { Strain }\end{array}$} & \multirow{2}{*}{$n$} & \multicolumn{2}{|c|}{ Model parameters ${ }^{\mathrm{a}}$} & \multicolumn{2}{|c|}{ Lethal concentrations ${ }^{\mathrm{b}}(\mathrm{mg} / \mathrm{L})$} & \multicolumn{2}{|c|}{ Model fit } \\
\hline & & & Intercept $\pm \mathrm{SE}$ & Slope \pm SE & $\begin{array}{l}\mathrm{LC}_{50} \\
(95 \% \mathrm{CI})\end{array}$ & $\begin{array}{c}\mathrm{LC}_{95} \\
(95 \% \mathrm{CI})\end{array}$ & $x^{2}$ & $P$ \\
\hline \multirow{2}{*}{ DDT } & Gorakhpur & 300 & $1.04(0.17)$ & $2.54(0.336)$ & $\begin{array}{c}0.51 \\
(0.40-0.63)\end{array}$ & $\begin{array}{c}3.40 \\
(2.26-6.37)\end{array}$ & 35.25 & $<0.0001$ \\
\hline & Pune & 300 & $0.58(0.14)$ & $1.99(0.28)$ & $\begin{array}{c}0.39 \\
(0.32-0.49) \\
\end{array}$ & $\begin{array}{c}1.72 \\
(1.27-2.67) \\
\end{array}$ & 17.49 & $<0.0001$ \\
\hline \multirow{2}{*}{ Deltamethrin } & Gorakhpur & 300 & $10.06(1.23)$ & $2.77(0.39)$ & $\begin{array}{c}0.0002 \\
(0.00019-0.00027)\end{array}$ & $\begin{array}{c}0.00092 \\
(0.0007-0.0013)\end{array}$ & 66.85 & $<0.0001$ \\
\hline & Pune & 300 & $10.07(1.18)$ & $2.9(0.34)$ & $\begin{array}{c}0.00023 \\
(0.00019-0.00028)\end{array}$ & $\begin{array}{c}0.00092 \\
(0.0007-0.001)\end{array}$ & 72.48 & $<0.0001$ \\
\hline \multirow{2}{*}{ Malathion } & Gorakhpur & 300 & $3.28(0.39)$ & $2.42(0.277)$ & $\begin{array}{c}0.10 \\
(0.080-0.12)\end{array}$ & $\begin{array}{c}0.67 \\
(0.44-1.23)\end{array}$ & 69.52 & $<0.0001$ \\
\hline & Pune & 300 & $1.99(0.29)$ & $1.98(0.24)$ & $\begin{array}{c}0.044 \\
(0.037-0.053)\end{array}$ & $\begin{array}{c}0.21 \\
(0.16-0.32)\end{array}$ & 45.03 & $<0.0001$ \\
\hline
\end{tabular}

${ }^{\mathrm{a}}$ The intercept and slope parameters are for logistic models in which the independent variable is natural logarithm of dose. Standard errors (SEs) for these values are shown in parentheses.

${ }^{\mathrm{b}} \mathrm{LC}_{50}$ and $\mathrm{LC}_{95}$ value; confidence intervals (CIs) for these values are shown in parentheses.

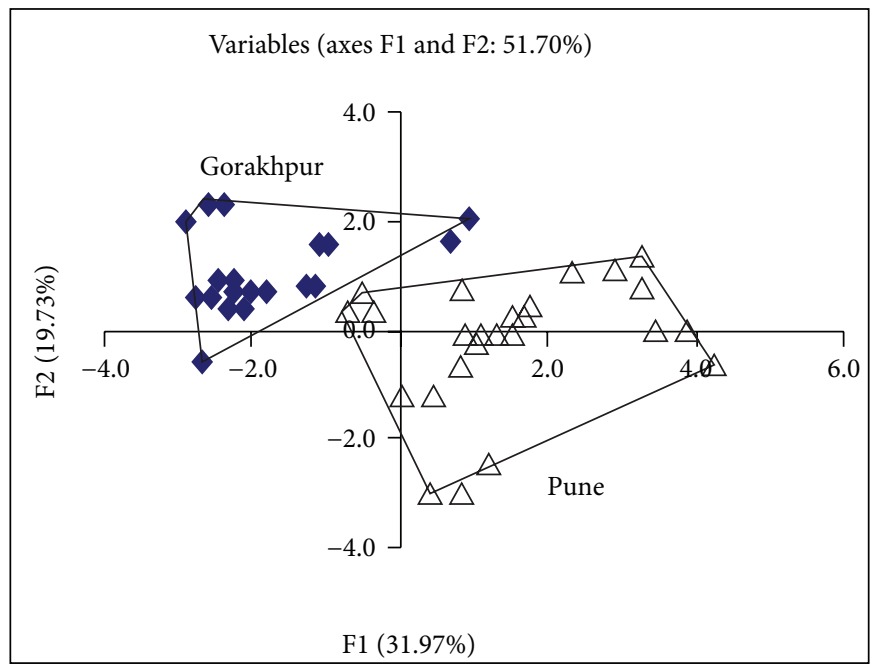

(a)

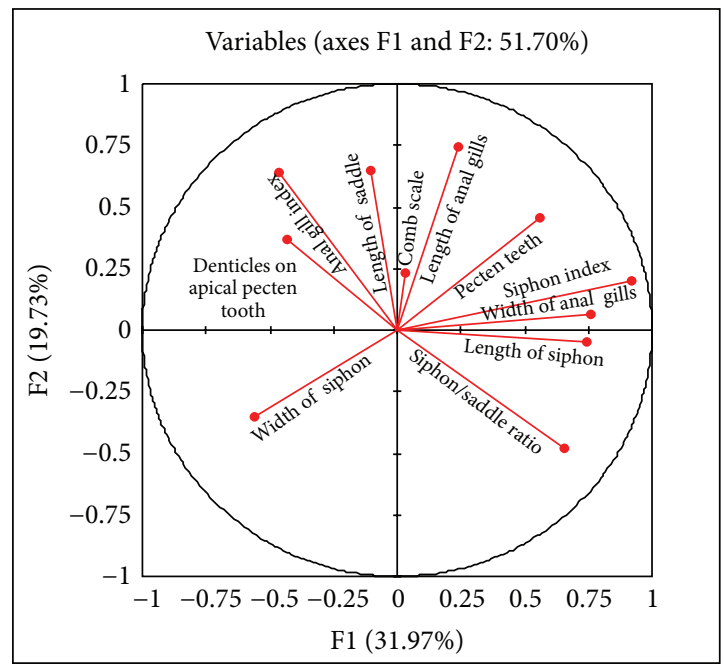

(b)

Figure 3: Principal component analysis (PCA) of morphological data. (a) Clusters of different populations. (b) Variables which discriminate between the clusters.

fatigans (synonymous with Cx. quinquefasciatus; Gomez et al. [37]), 79.6\% in Cx. quinquefasciatus (Suleman and Reisen [38]), and $80.5 \%-95.6 \%$ in Cx. quinquefasciatus (Suman et al. [28]; five populations from India) which are close to the values reported in the present study (Table 1). The mean development time from egg to adult was found to vary little, with showing a range of $\leq 1$ day (15.4 days in Gorakhpur and 16.5 days in Pune). These values were higher than the developmental period reported for $C x$. quinquefasciatus collected from Bikaner, Jamnagar, and Bhatinda areas of India [28]. It has been documented that variations in immature mosquito developmental rates depend on habitat conditions $[28,39-42]$. The results obtained in this study also suggest that habitat and environmental conditions play important role in biological attributes of mosquitoes.

Life expectancy is an important attribute of vector capacity as it plays important role in transmission pathogens. Studies on lymphatic filariasis transmission indicate that microfilariae require 16-17 days in the mosquito vector to reach the infective stage [43]. This period shortens with higher temperature and humidity [44] but increases up to 42 days at lower temperatures [45]. As life table analysis suggests that Gorakhpur population invest more energy in reproduction it is likely to take blood meal more frequently. The repeated biting may cause spread of diseases rapidly. Higher ambient temperatures and frequent biting nature of 
Cx. quinquefasciatus of Gorakhpur might be responsible for frequent cases of lymphatic filariasis in this area.

Multivariate analysis of morphological characters revealed that two populations of $C x$. quinquefasciatus differ significantly in morphological characters (Table 2; Figure 3(a)). Principal component analysis of the data suggested that siphon, saddle, anal gills and pecten teeth related variables were the most important distinguishing characters (Figure 3(b)). Anal gills are longer in Gorakhpur population as compared to Pune population (Table 3). As salt concentration of water increases the length of anal gills starts reducing [46]. The salt concentration of Pune water might be a probable reason behind the reduced anal gill length. The causes of morphological differences between populations are often quite difficult to explain. Phenotype is under the double control of environmental conditions and genotype, but morphological changes can be rapid when different environmental conditions occur [47]. We hypothesize that transition of saddle and anal gill length in $C x$. quinquefasciatus populations is a consequence of environmental conditions selection.

The history of insecticide resistance in Culex species suggests that members of Culex genus have a notorious reputation for developing resistance to insecticides, including organophosphates, carbamates, and pyrethroids $[17,21,22$, $48,49]$. In India, first evidence of development of DDT resistance in $C x$. quinquefasciatus was observed in 1952 from a village near Delhi [50]. Later, several areas like Nagpur, Pune, Patna, and Rajahmundry reported resistance in Culex mosquitoes to various insecticides such as BHC, fenitrothion, DDT, malathion, and temephos $[15,16,18,20$, 23,51 ]. Investigation by Mukhopadhyay et al. [23] showed no mortality in Cx. quinquefasciatus adults against the 4\% DDT and $5 \%$ malathion. About $8 \%$ and $14 \%$ mortality were found in $C x$. quinquefasciatus larvae in 0.125 and $3.125 \mathrm{mg} / \mathrm{l} \mathrm{con-}$ centration of DDT and malathion, respectively. The present study concludes that the larvae of both the populations of $C x$. quinquefasciatus are highly susceptible to deltamethrin. However, $C x$. quinquefasciatus populations in these areas showed resistance to DDT and malathion. Therefore, as a baseline study it may be concluded that in future prudent use of vector control strategies should be applied to reduce the Cx. quinquefasciatus nuisance in Gorakhpur and Pune.

In summary, this study provides baseline information on survivorship, morphological variation, and insecticide susceptibility of Culex quinquefasciatus populations. The climate conditions of Pune seems more permissive to the development and survival of Culex quinquefasciatus. The insecticide susceptibility results revealed that in the future different control measures will be required to reduce the $C x$. quinquefasciatus populations. This knowledge, coupled with enhanced understanding of the ecology of $C x$. quinquefasciatus, will enable locally specific, efficient deployment of public health resources in reducing the burden of $C x$. quinquefasciatus.

\section{Conflict of Interests}

The authors have declared that no competing interests exist.

\section{Funding}

The study was supported by the Indian Council of Medical Research, Government of India. The funding agency had no role in study design, data collection and analysis, decision to publish, or preparation of the paper.

\section{Acknowledgments}

The authors thank Dr. A. C. Mishra, Director, National Institute of Virology, Pune, for the facilities and encouragement. They appreciate the technical assistance provided by the field staff of NIV. They are thankful to Dr. Neelesh Dahanukar, IISER, Pune, for the valuable suggestions and help in statistical analysis.

\section{References}

[1] R. Maharaj, "Life table characteristics of Anopheles arabiensis (Diptera: Culicidae) under simulated seasonal conditions," Journal of Medical Entomology, vol. 40, no. 6, pp. 737-742, 2003.

[2] S. M. M. Ahid, P. S. Da Silva Vasconcelos, and R. Lourençode-Oliveira, "Vector competence of Culex quinquefasciatus Say from different regions of Brazil to Dirofilaria immitis," Memorias do Instituto Oswaldo Cruz, vol. 95, no. 6, pp. 769-775, 2000.

[3] C. A. Lima, W. R. Almeida, H. Hurd, and C. M. R. Albuquerque, "Reproductive aspects of the mosquito Culex quinquefasciatus (Diptera: Culicidae) infected with Wuchereria bancrofti (Spirurida: Onchocercidae)," Memorias do Instituto Oswaldo Cruz, vol. 98, no. 2, pp. 217-222, 2003.

[4] C. van Riper III, S. G. van Riper, M. L. Goff, and M. Laird, “The epizootiology and ecological significance of malaria in Hawaiian land birds," Ecology Monograph, vol. 56, pp. 327-344, 1986.

[5] R. P. Meyer, J. L. Hardy, and S. B. Presser, "Comparative vector competence of Culex tarsalis and Culex quinquefasciatus from the Coachella, Imperial, and San Joaquin Valleys of California for St. Louis encephalitis virus," American Journal of Tropical Medicine and Hygiene, vol. 32, no. 2, pp. 305-311, 1983.

[6] S. Sucharit, K. Surathin, and S. R. Shrestha, "Vectors of Japanese encephalitis virus (JEV): species complexes of the vectors," The Southeast Asian Journal of Tropical Medicine and Public Health, vol. 20, no. 4, pp. 611-621, 1989.

[7] G. Aviles, M. S. Sabattini, and C. J. Mitchell, "Peroral susceptibility of Aedes albifasciatus and Culex pipiens complex mosquitoes (Diptera: Culicidae) from Argentina to western equine encephalitis virus," Revista de Saude Publica, vol. 24, no. 4, pp. 265-269, 1990.

[8] M. R. Sardelis, M. J. Turell, D. J. Dohm, and M. L. O'Guinn, "Vector competence of selected North American Culex and Coquillettidia mosquitoes for West Nile virus," Emerging Infectious Diseases, vol. 7, no. 6, pp. 1018-1022, 2001.

[9] G. Molaei, T. G. Andreadis, P. M. Armstrong et al., "Host feeding pattern of Culex quinquefasciatus (Diptera: Culicidae) and its role in transmission of West Nile virus in Harris County, Texas," American Journal of Tropical Medicine and Hygiene, vol. 77, no. 1, pp. 73-81, 2007.

[10] M. Das, "Vectors of filariasis with special reference to India," The Journal of Communicable Diseases, vol. 8, pp. 101-109, 1976.

[11] D. Singh, "The Culex pipiens fatigans problem in South-East Asia with special reference to urbanization," Bulletin of the World Health Organization, vol. 37, no. 2, pp. 239-243, 1967. 
[12] E. Michael and D. A. P. Bundy, "Global mapping of lymphatic filariasis," Parasitology Today, vol. 13, no. 12, pp. 472-476, 1997.

[13] E. Michael, D. A. P. Bundy, and B. T. Grenfell, "Re-assessing the global prevalence and distribution of lymphatic filariasis," Parasitology, vol. 112, no. 4, pp. 409-428, 1996.

[14] R. K. Shenoy, "Management of disability in lymphatic filariasis-an update," Journal of Communicable Diseases, vol. 34, no. 1, pp. 1-14, 2002.

[15] N. Rajagopalan, J. C. Vedamanickam, and S. R. Ramani, "Development of resistance to BHC by C. fatigans in the course of a larva control programme," Bulletin of Natural Society of India Malaria Control, vol. 2, pp. 211-213, 1954.

[16] P. Krishnarao, V. K. Raina, and T. K. Ghosh, "Susceptibility status of Culex quinquefasciatus (Rajahmundry strain) to insecticides," Journal of Communicable Diseases, vol. 21, no. 2, pp. 145-147, 1989.

[17] J. A. Bisset, M. M. Rodriguez, J. Hemingway, C. Diaz, G. J. Small, and E. Ortiz, "Malathion and pyrethroid resistance in Culex quinquefasciatus from Cuba: efficacy of pirimiphos-methyl in the presence of at least three resistance mechanisms," Medical and Veterinary Entomology, vol. 5, no. 2, pp. 223-228, 1991.

[18] A. K. Mukhopadhyay, S. N. Sinha, R. L. Yadav, and M. V. Narasimham, "Susceptibility status of Culex quinquefasciatus in Patna to insecticides," Indian Journal of Public Health, vol. 37, no. 2, pp. 57-60, 1993.

[19] L. J. Kanhekar, S. K. Patnaik, P. K. Rao, M. V. Narayana, V. K. Raina, and A. Kumar, "Some aspects of the bionomics of Culex quinquefasciatus (Diptera: Culicidae) in Rajahmundry town, Andhra Pradesh," Journal of Communicable Diseases, vol. 26, no. 4, pp. 226-230, 1994.

[20] S. K. Patnaik, L. J. Kanhekar, P. Krishna Rao, V. K. Raina, and A. Kumar, "A study to evaluate the impact of different dose/frequency of Temephos $50 \%$ EC for control of $C x$. quinquefasciatus vector of bancroftian filariasis," Journal of Communicable Diseases, vol. 29, no. 2, pp. 171-174, 1997.

[21] F. Chandre, F. Darriet, M. Darder et al., "Pyrethroid resistance in Culex quinquefasciatus from West Africa," Medical and Veterinary Entomology, vol. 12, no. 4, pp. 359-366, 1998.

[22] S. Kasai, I. S. Weerashinghe, and T. Shono, "P450 monooxygenases are an important mechanism of permethrin resistance in Culex quinquefasciatus Say larvae," Archives of Insect Biochemistry and Physiology, vol. 37, no. 1, pp. 47-56, 1998.

[23] A. K. Mukhopadhyay, S. K. Patnaik, and P. Satya Babu, "Susceptibility status of some culicine mosquitoes to insecticides in Rajahmundry town of Andhra Pradesh, India," Journal of Vector Borne Diseases, vol. 43, no. 1, pp. 39-41, 2006.

[24] S. McCann, J. F. Day, S. Allan, and C. C. Lord, "Age modifies the effect of body size on fecundity in Culex quinquefasciatus say (Diptera: Culicidae)," Journal of Vector Ecology, vol. 34, no. 2, pp. 174-181, 2009.

[25] D. S. Suman, A. R. Shrivastava, B. D. Parashar, S. C. Pant, O. P. Agrawal, and S. Prakash, "Variation in morphology and morphometries of eggs of Culex quinquefasciatus mosquitoes from different ecological regions of India," Journal of Vector Ecology, vol. 34, no. 2, pp. 191-199, 2009.

[26] S. A. de Morais, C. Moratore, L. Suesdek, and M. T. Marrelli, "Genetic-morphometric variation in Culex quinquefasciatus from Brazil and La Plata, Argentina," Memorias do Instituto Oswaldo Cruz, vol. 105, no. 5, pp. 672-676, 2010.

[27] M. B. Kaliwal, A. Kumar, A. B. Shanbhag, A. P. Dash, and S. B. Javali, "Spatio-temporal variations in adult density, abdominal status \& indoor resting pattern of Culex quinquefasciatus Say in Panaji, Goa, India," Indian Journal of Medical Research, vol. 131, no. 5, pp. 711-719, 2010.

[28] D. S. Suman, S. N. Tikar, M. J. Mendki et al., "Variations in life tables of geographically isolated strains of the mosquito Culex quinquefasciatus," Medical and Veterinary Entomology, vol. 25, no. 3, pp. 276-288, 2011.

[29] P. J. Barraud, The Fauna of British India Including Ceylon and Burma, Today and Tomorrow's Printers and Publishers, New Delhi, India, 1934.

[30] W. K. Reisen, T. F. Siddiqui, Y. Aslam, and G. M. Malik, "Geographic variation among the life table characteristics of Culex tritaeniorhynchus from Asia," Annals of Entomological Society of America, vol. 72, pp. 700-709, 1979.

[31] M. R. Fakoorziba and V. A. Vijayan, "Variation in morphological characters of Culex tritaeniorhynchus (Diptera: Culicidae), a Japanese encephalitis vector at Mysore, India," Journal of Communicable Diseases, vol. 35, no. 3, pp. 206-213, 2003.

[32] P. C. Kanojia, M. S. Paingankar, A. A. Patil, M. D. Gokhale, and D. N. Deobagkar, "Morphometric and allozyme variation in Culex tritaeniorhynchus mosquito populations from India," Journal of Insect Science, vol. 10, article no. 138, 2010.

[33] W. S. Abbott, "A method of computing the effectiveness of an insecticide," Journal of Economic Entomology, vol. 18, pp. 265267, 1925.

[34] J. E. Throne, D. K. Weaver, and J. E. Baker, "Probit analysis: assesing goodness of fit based on backtransformation and residuals," Journal of Economic Entomology, vol. 88, pp. 15131516, 1995.

[35] F. Matsumura, Toxicology of Insects, Plenum Press, New York, NY, USA, 2nd edition, 1985.

[36] WHO, “Test procedures for secticide resistance monitoring in malaria vectors, bio-efficacy and persistence of insecticides on treated surfaces," Tech. Rep. WHO/CDS/MAL/98.12, World Health Organization, Geneva, Switzerland, 1998.

[37] C. Gomez, J. E. Rabinovich, and C. E. Machado Allison, "Population analysis of Culex pipiens fatigans wied. (Diptera: Culicidae) under laboratory conditions," Journal of Medical Entomology, vol. 13, no. 4-5, pp. 453-463, 1977.

[38] M. Suleman and W. K. Reisen, "Culex quinquefasciatus Say: life table characteristics of adults reared from wild-caught pupae from North West Frontier Province, Pakistan," Mosquito News, vol. 39, pp. 756-762, 1979.

[39] G. R. A. Okogun, "Life-table analysis of Anopheles malaria vectors: generational mortality as tool in mosquito vector abundance and control studies," Journal of Vector Borne Diseases, vol. 42, no. 2, pp. 45-53, 2005.

[40] H. Yurttas and B. Alten, "Geographic differentiation of life table attributes among Anopheles sacharovi (Diptera: Culicidae) populations in Turkey," Journal of Vector Ecology, vol. 31, no. 2, pp. 275-284, 2006.

[41] Y. A. Afrane, G. Zhou, B. W. Lawson, A. K. Githeko, and G. Yan, "Life-table analysis of Anopheles arabiensis in western Kenya highlands: effects of land covers on larval and adult survivorship," American Journal of Tropical Medicine and Hygiene, vol. 77, no. 4, pp. 660-666, 2007.

[42] I. K. Olayemi and A. T. Ande, "Life table analysis of Anopheles gambiae (Diptera: Culicidae) in relation to malaria transmission," Journal of Vector Borne Diseases, vol. 46, no. 4, pp. 295298, 2009. 
[43] T. L. Bancroft, "On the metamorphosis of the young form of Filaria bancrofti Cobb," Journal of Proceedings of the Royal Society of New South Wales, vol. 82, pp. 62-65, 1899.

[44] G. Chandra, S. N. Chatterjee, B. D. Banerjee, and G. Majumdar, "Effect of seasonal variations on the development of Wuchereria larvae in Culex quinquefasciatus," Basic and Applied Biomedical Sciences, vol. 5, pp. 21-24, 1997.

[45] P. E. C. Manson-Bahr and D. R. Bell, Manson's Tropical Disease, ELBS Publishers, London, UK, 2003.

[46] V. B. Wiggleworth, "The function of anal gills of the mosquito larva," Journal of Experimental Biology, vol. 10, pp. 16-26, 1933.

[47] T. Klepaker, "Morphological changes in a marine population of threespined stickleback, Gasterosteus aculeatus, recently isolated in fresh water," Canadian Journal of Zoology, vol. 71, no. 6, pp. 1251-1258, 1993.

[48] H. Ben Cheikh, Z. Ben Ali-Haouas, M. Marquine, and N. Pasteur, "Resistance to organophosphorus and pyrethroid insecticides in Culex pipiens (Diptera: Culicidae) from Tunisia," Journal of Medical Entomology, vol. 35, no. 3, pp. 251-260, 1998.

[49] V. Corbel, S. Duchon, M. Zaim, and J.-M. Hougard, "Dinotefuran: a potential neonicotinoid insecticide against resistant mosquitoes," Journal of Medical Entomology, vol. 41, no. 4, pp. 712717, 2004.

[50] A. W. A. Brown and R. Pal, Insecticide Resistance in Arthropod, World Health Organization, Geneva, Switzerland, 1971.

[51] H. M. Tahir, A. Butt, and S. Y. Khan, "Response of Culex quinquefasciatus to deltamethrin in Lahore district," Journal of Parasitology and Vector Biology, vol. 1, no. 3, pp. 19-24, 2009. 

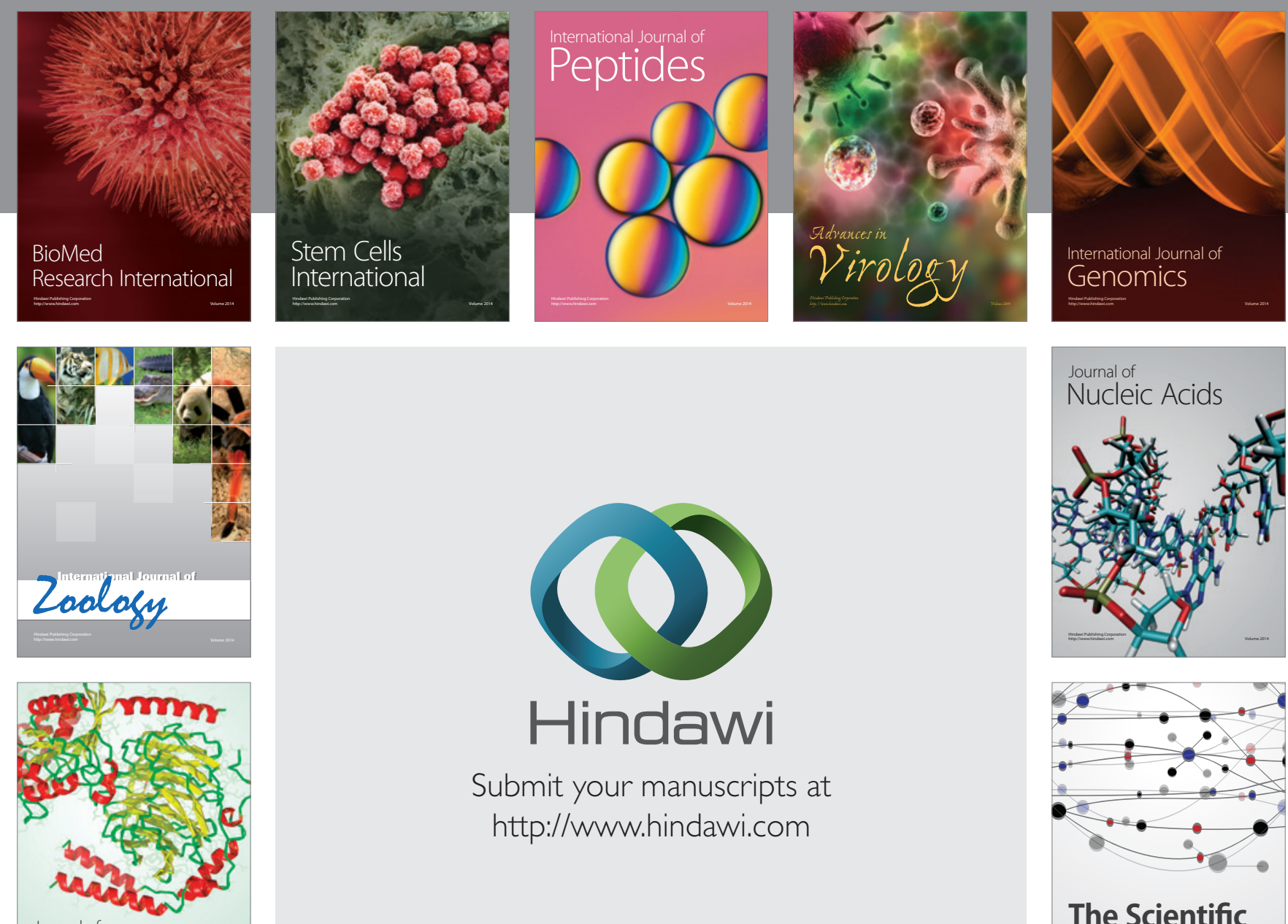

Submit your manuscripts at

http://www.hindawi.com

Journal of
Signal Transduction
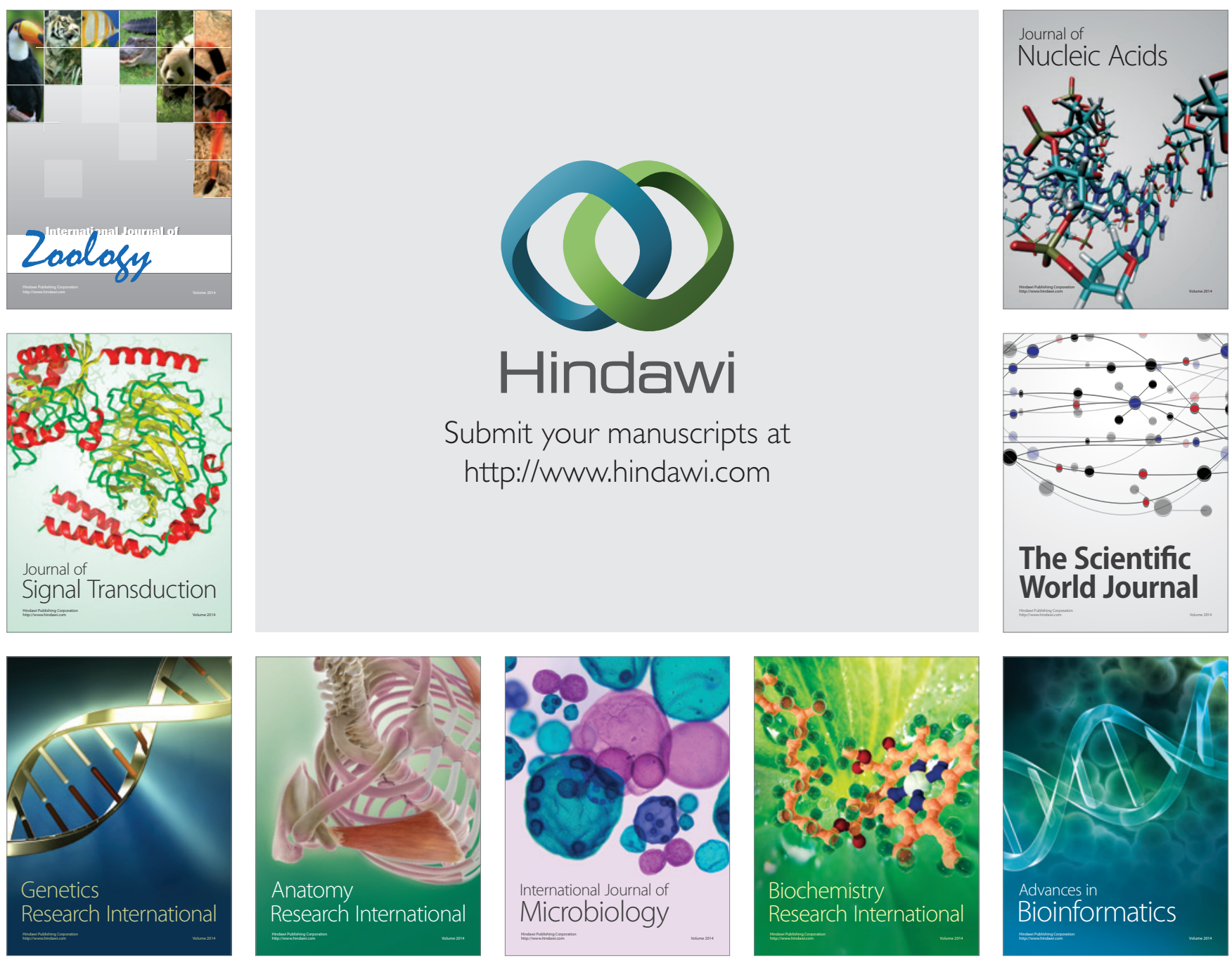

The Scientific World Journal
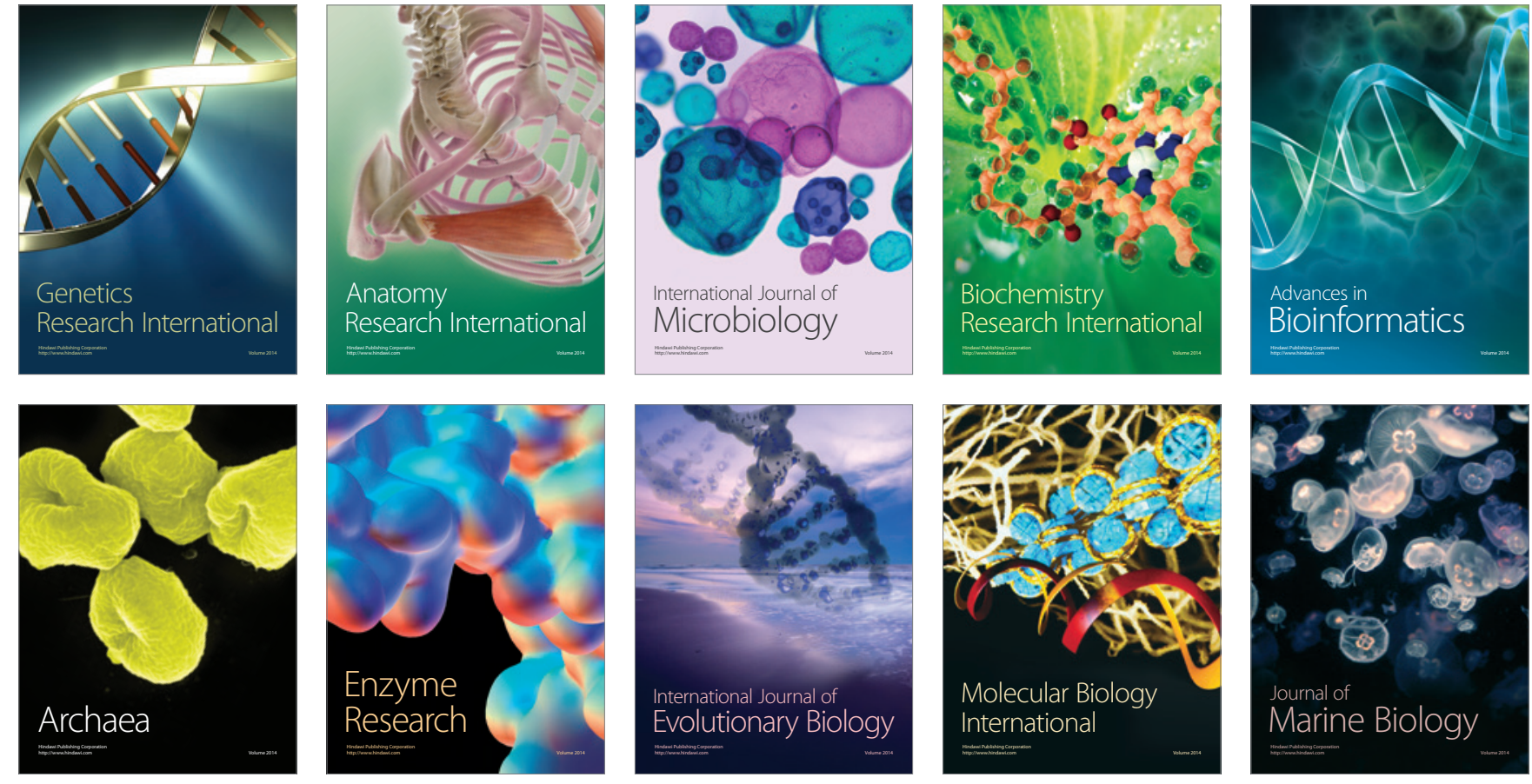